\title{
Respons Pertumbuhan dan Produksi Tanaman Kedelai (Glycine max (L.) Merr) Terhadap Pemberian Alelopati Lalang (Imperata cylindrica) dan Babadotan (Ageratum conyzoides)
}

Response of growth and production of soybean crops (Glycine max (L.) Merr) with giving cocongrass allelopathy (Imperata cilindrica) and billy-goat weed (Ageratum conyzodes)

\section{Andreansyah, T. Irmansyah*, Meiriani}

Program Studi Agroekoteknologi, Fakultas Pertanian, USU, Medan 20155

*Corresponding author : omanteungoh@gmail.com

\section{ABSTRACT}

This research was conducted to determine the respons of growth and production of soybean crops with giving cocongrass allelopathy (Imperata cylindrica) and billy-goat weed allelopathy (Agratum conyzoides) at faculty of agriculture, north sumatera university, Medan, from april to july 2017. This research using nonfactorial randomized block design with allelopathy extract factor, that are coconggrass allelopathy 0,50,100,150 ml and billy-goat weed allelopathy 50, 100, $150 \mathrm{ml}$. The result showed that allelopathy of billy goat weed had significantly decreased stem diameter, amounts of empty pods, amount of filled pods, amounts of branches of soybean crop.

Key word : allelophaty, soybean, cocongrass, billy-goat weed.

\begin{abstract}
ABSTRAK
Penelitian ini di lakukan untuk mengetahui respons pertumbuhan dan produksi tanaman kedelai (Glycine Max) terhadap pemberian alelopati lalang ( Imperata cylindrica) dan babadotan (Ageratum Conyzoides yang di laksanakan di lahan Fakultas Pertanian Universitas Sumatera Utara yang di mulai pada bulan April sampai bulan juli 2017, menggunakan rancangan acak kelompok non faktorial, dengan perlakuan ekstrak alelopati lalang dengan 0, 50, 100, $150 \mathrm{ml}$ dan ekstrak alelopati babadotan dosis 50, 100, $150 \mathrm{ml}$. Hasil penelitian menunjukan pemberian alelopati babadotan berpengaruh nyata terhadap parameter diameter batang, jumlah polong hampa, jumlah polong berisi, cabang produktif.
\end{abstract}

Kata Kunci : alelopati, kedelai, lalang, babadotan.

\section{PENDAHULUAN}

Alelopati merupakan suatu istilah yang telah lama dikenal berasal dari kata allelon (saling) dan pathos (menderita), alelopati meliputi interaksi biokimia secara timbal balik, merupakan senyawa yang bersifat menghambat maupun memacu antara semua jenis tumbuhan termasuk mikroorganisme (Junaedi et al. 2006 ).

Hasil penelitian dari Hafsah (2012) menyatakan bahwa cairan perasan daun Ageratum conyzoides pada konsentrasi $100 \mathrm{~g} / \mathrm{l}$ sudah mampu menghambat perkecambahan, bahkan pada konsentrasi 500 g/l mampu menghambat perkecambahan $100 \%$, penghambatan juga terjadi pada peubah tinggi tanaman, jumlah akar dan bobot kering tanaman.

Lalang menghambat pertumbuhan tanaman jagung dengan menggunakan percobaan pot-pot bertingkat di rumah kaca di Bogor, mengingat unsur hara, air dan cahaya bukan merupakan pembatas utama, maka diduga bahwa alang-alang merupakan senyawa beracun yang dapat mempengaruhi pertumbuhan jagung. Tumbuhan yang telah mati dan sisa-sisa tumbuhan yang dibenamkan 
ke dalam tanah juga dapat menghambat pertumbuhan jagung, memperlihatkan bahwa semakin tinggi konsentrasi ekstraks organ tubuh alang-alang, semakin besar pengaruh negatifnya terhadap pertumbuhan kecambah padi gogo (Sastrautomo, 1990). Oleh karena itu penulis ingin melakukan penelitian bagaimana respon pertumbuhan dan produksi tanaman kedelai terhadap pemberian alelopati lalang dan babadotan.

\section{BAHAN DAN METODE}

Penelitian ini dilaksanakan pada bulan April 2017 sampai dengan Bulan Juni di lahan Fakultas Pertanian, Program Studi Agroekoteknologi, Fakultas Pertanian, Universitas Sumatera Utara, Medan.

Bahan yang digunakan pada penelitian ini adalah top soil, benih kedelai varietas Grobogan, akar alalang, akar babadotan, label, kain serbet, air, botol mineral 2 L. Alat yang digunakan pada penelitian ini adalah cangkul, blender, gunting, gelas ukur, timbangan,handsprayer, jangka sorong, ayakan, alat tulis, kamera.

Penelitian ini menggunakan Rancangan Acak Kelompok (RAK) Non Faktorial. faktor perlakuan yaitu :

Perlakuan alelopati yang terdiri dari 7 taraf yaitu P0 : tanpa pemberian alelopati, P1: pemberian alelopati lalang $50 \mathrm{ml} /$ aplikasi P2: pemberian alelopati lalang $100 \mathrm{ml} /$ aplikasi P3: pemberian alelopati lalang $150 \mathrm{ml} \mathrm{/}$ aplikasi P4: pemberian alelopati babadotan 50 ml / aplikasi P5 : pemberian alelopati babadotan $100 \mathrm{ml} /$ aplikasi P6 : pemberian alelopati babadotan $150 \mathrm{ml} /$ aplikasi alelopati dilakukan saat tanaman berumur 2 MST, 4 MST, 6 MST, 8 MST dan 10 MST, pemupukan menggunakan Urea dengan dosis 0,25 gr/polibeg, TSP 0,50 gr/polibeg, $\mathrm{KCl}$ 0,38 gr/polibeg, diaplikasikan pada saat penanaman dan 4 MST dengan dosis yang sama. Pemeliharaan yang terdiri dari penyiraman yang dilakukan pada sore hari, penyiangan apabila terdapat gulma pada lahan, serta kegiatan pengendalian hama dan penyakit apabila tanaman terserang hama dan penyakit.
Peubah yang diamati tinggi tanaman, diameter batang, umur berbunga, cabang produktif jumlah polong berisi, jumlah polong hampa, bobot biji dan umur panen. Data dianalisis dengan sidik ragam, sidik ragam yang nyata dilanjutkan dengan menggunakan Uji Jarak Berganda Duncan dengan taraf $\alpha=5 \%$.

\section{HASIL DAN PEMBAHASAN}

\section{Tinggi tanaman}

Tabel 1 menunjukkan tanaman kedelai tertinggi $(40,44 \mathrm{~cm})$ cenderung diperoleh pada perlakuan pemberian tanpa alelopati $\left(\mathrm{P}_{0}\right)$ yang berbeda tidak nyata dengan perlakuan lainnya.

Hasil pengamatan terhadap tinggi tanaman kedelai akibat pemberian ekstrak alelopati lalang dan bandotan menunjukkan terjadi penekanan pertumbuhan tanaman kedelai. Dari hasil pengamatan tersebut, terlihat rata-rata tinggi tanaman yang paling tinggi adalah pada perlakuan kontrol yaitu 44 $\mathrm{cm}$ sedangkan yang terendah adalah pada perlakuan ekstrak bandotan $150 \mathrm{ml}$ yaitu 6,90 $\mathrm{cm}$. Berdasarkan hasil tersebut, dapat diketahui bahwa pemberian cairan ekstrak $A$, conyzoides dapat menekan pertumbuhan tanaman kedelai, dikarenakan pada gulma $A$, conyzoides mengandung bahan kimia yang dikenal dengan istilah alelopati di mana suatu senyawa yang dikeluarkan untuk menghambat pertumbuhan tanaman, sehingga fotosintesis, respirasi akan terganggu yang menyebabkan terganggunya pertumbuhan tanaman. Hal ini sesuai dengan pernyataan Weston (1996) yang menyatakan alelopati merupakan pelepasan senyawa bersifat toksik yang dapat mengganggu pertumbuhan tanaman disekitarnya dan senyawa yang bersifat alelokimia, Beberapa senyawa alelopati menghambat pembelahan sel-sel akar, menghambat pertumbuhan yaitu dengan mempengaruhi pembesaran sel, menghambat respirasi akar, menghambat sintesis protein, menghambat aktivitas enzim dan menurunkan daya permeabilitas membran pada sel tumbuhan 
Tabel 1. Tinggi dan bobot biji tanaman kedelai pada perlakuan pemberian alelopati lalang (Imperata cylindrica) dan babadotan (Ageratum conyzoides)

\begin{tabular}{lcc}
\hline Pemberian alelopati & Tinggi & Bobot biji \\
\hline $\mathrm{P}_{0}($ tanpa ektrak ) & 40,44 & 8,03 \\
$\mathrm{P}_{1}($ 50 ml akar lalang $)$ & 37,83 & 6,57 \\
$\mathrm{P}_{2}(100 \mathrm{ml}$ akar lalang $)$ & 39,27 & 7,45 \\
$\mathrm{P}_{3}(150 \mathrm{ml}$ akar lalang $)$ & 34,39 & 6,25 \\
$\mathrm{P}_{4}(50 \mathrm{ml}$ akar babadotan $)$ & 38,07 & 5,83 \\
$\mathrm{P}_{5}(100 \mathrm{ml}$ akar babadotan $)$ & 35,84 & 6,17 \\
$\mathrm{P}_{6}(150 \mathrm{ml}$ akar babadotan $)$ & 32,62 & 5,85 \\
\hline Rataan & 36,92 & 6,59 \\
\hline
\end{tabular}

\section{Bobot Biji}

Bobot biji tanaman kedelai pada pemberian alelopati lalang (Imperata cylindrica ) dan babadotan (Ageratum conyzoides) dapat dilihat pada Tabel 1.

Tabel 1 menunjukkan bobot biji kedelai terberat $(8,03 \mathrm{~g})$ cenderung diperoleh pada pemberian tanpa alelopati $\left(\mathrm{P}_{0}\right)$ yang berbeda tidak nyata dengan $\mathrm{P}_{1}, \mathrm{P}_{2}, \mathrm{P}_{3}, \mathrm{P}_{4}, \mathrm{P}_{5}$ dan $\mathrm{P}_{0}$.

Hasil pengamatan terhadap bobot biji tanaman kedelai akibat pemberian ekstrak alelopati lalang dan bandotan menunjukkan terjadi penurunan produksi tanaman kedelai. Dari hasil pengamatan tersebut, terlihat rataan bobot biji terendah $(5,83 \mathrm{~g})$ yaitu pada pemberian $50 \mathrm{ml}$ babadotan. Hal ini diduga karena pertumbuhan vegetative tanaman terganggu sehingga hasil produksi akan menurun. Penurunan ini disebabkan karena senyawa alelopati menghambat metabolisme dalam tubuh tanaman. Hal ini sesuai dengan pernyataan Weston (1996 ) bahwa alelopati merupakan pelepasan senyawa bersifat toksik yang dapat mengganggu pertumbuhan tanaman disekitarnya dan senyawa yang bersifat alelopati disebut alelokimia. Beberapa senyawa alelopati menghambat pembelahan sel-sel akar, menghambat pertumbuhan yaitu dengan mempengaruhi pembesaran sel, menghambat respirasi akar, menghambat sintesis protein, menghambat aktivitas enzim, serta menurunkan daya permeabilitas membran pada sel tumbuhan.

\section{Diameter Batang}

Diameter batang tanaman kedelai pada perlakuan pemberian alelopati lalang (Imperata cylindrica ) dan babadotan (Ageratum conyzoides) umur 4 MST dapat dilihat pada Tabel 2.

Tabel 2 menunjukkan diameter tanaman kedelai terbesar $(4,51 \mathrm{~mm})$ diperoleh pada perlakuan pemberian tanpa ekstrak alelopati $\left(\mathrm{P}_{0}\right)$ yang berbeda tidak nyata dengan $\mathrm{P}_{1}, \mathrm{P}_{2}$ tetapi berbeda nyata dengan $\mathrm{P}_{3}, \mathrm{P}_{4}, \mathrm{P}_{5}$ dan $\mathrm{P}_{6}$.

Hasil analisis yang di peroleh bahwa pemberian alelopati babandotan $150 \mathrm{ml}$ (P6) menurunkan diameter batang tanaman kedelai. Hal ini mengindikasikan bahwa alelopati yang di berikan mampu menurunkan diameter batang tanaman karena bersifat toksik yang dapat mempengaruhi pertumbuhan tanaman. Hal ini sejalan dengan pendapat Togatorop (2009), bahwa ekstrak Ageratum conyzoides dapat menekan panjang kecambah bagian atas pada sawi yang disebabkan oleh adanya senyawa phenolic acid yang terkandung pada Ageratumconyzoides 
Tabel 2. Diameter dan polong berisi tanaman kedelai pada perlakuan pemberian alelopati lalang (Imperata cylindrica) dan babadotan (Ageratum conyzoides)

\begin{tabular}{lcc} 
Pemberian alelopati & Diameter & Jumlah Polong berisi \\
\hline $\mathrm{P}_{0}($ tanpa ektrak ) & $4,51 \mathrm{a}$ & $39,53 \mathrm{a}$ \\
$\mathrm{P}_{1}(50 \mathrm{ml}$ akar lalang $)$ & $4,21 \mathrm{ab}$ & $32,27 \mathrm{bc}$ \\
$\mathrm{P}_{2}(100 \mathrm{ml}$ akar lalang $)$ & $4,27 \mathrm{ab}$ & $35,67 \mathrm{ab}$ \\
$\mathrm{P}_{3}(150 \mathrm{ml}$ akar lalang $)$ & $3,82 \mathrm{bc}$ & $27,87 \mathrm{c}$ \\
$\mathrm{P}_{4}(50 \mathrm{ml}$ akar babadotan $)$ & $4,04 \mathrm{bc}$ & $28,00 \mathrm{c}$ \\
$\mathrm{P}_{5}(100 \mathrm{ml}$ akar babadotan $)$ & $3,83 \mathrm{bc}$ & $28,60 \mathrm{bc}$ \\
$\mathrm{P}_{6}(150 \mathrm{ml}$ akar babadotan $)$ & $\mathrm{e} 3,56 \mathrm{c}$ & $25,00 \mathrm{c}$ \\
\hline Rataan & 4,03 & 30,99 \\
\hline
\end{tabular}

Keterangan: Angka yang diikuti oleh huruf yang sama pada kolom yang sama menunjukkan berbeda tidak nyata menurut Uji Jarak Berganda Duncan pada taraf $\alpha=5 \%$

\section{Jumlah Polong Berisi}

Tabel 2 menunjukkan jumlah polong berisi kedelai terbanyak (39,53 polong) diperoleh pada perlakuan tanpa pemberian alelopati $\left(\mathrm{P}_{0}\right)$ yang berbeda tidak nyata dengan $\mathrm{P}_{2}$ tetapi berbeda nyata dengan $\mathrm{P}_{1}, \mathrm{P}_{3}$, $\mathrm{P}_{4}, \mathrm{P}_{5}$ dan $\mathrm{P}_{6}$.

Hasil analisis yang di peroleh di ketahui bahwa pemberian alelopati berpengaruh nyata terhadap parameter jumlah polong berisi. Hal ini mengindikasikan bahwa alelopati yang di berikan mampu menurunkan produksi tanaman kedelai yang di sebabkan alelopati mengandung toksik. Hal ini sesuai dengan Hasil penelitian Inawati (2000) menunjukkan bahwa kehadiran gulma $A$, conyzoides dan $C$, rotundus pada pertanaman kedelai dapat menurunkan produksi masingmasing sebesar $21,72 \%$ dan $37 \%, D$, adscendens dapat menurunkan hasil tanaman bawang merah sekitar $43,5 \%$

\section{SIMPULAN}

Pemberian alelopati babadotan $150 \mathrm{ml}$ memberi respon yang nyata menurunkan diameter batang dan jumlah polong berisi tanaman kedelai.

\section{DAFTAR PUSTAKA}

Inawati, L. 2000. Pengaruh jenis gulma terhadap pertumbuhan, pembentukan bintil akar dan produksi tiga varietas kedelai (Glycine $\max (\mathrm{L}$,$) Merr,),$ Skripsi, Jurusan Budidaya Pertanian, Fakultas Pertanian, Institut Pertanian Bogor.

Junaedi, A, M,A, Chozin dan K, Ho Kim, 2006. Ulasan perkembangan terkini kajian alelopati (Current research status of allelopathy),

Sastroutomo, S,S,, 1990. Ekologi gulma, Penerbit PT Gramedia Pustaka utama Jakarta

Siti, H. 2012. Efek Alelopati Ageratum Conyzoides Terhadap Pertumbuhan Sawi, Program Studi Agroteknologi Fakulas Pertanian, Universitas Syiah Kuala, Banda Aceh Sutopo, L. 2002. Teknologi Benih. Raja Grafindo Persada, Jakarta.

Togatorop, D, A, 2009, Studi Alelopati Wedelia tribobata, Ageratum conyzoides, Chromolaena odorata dan Mikania micrantha Terhadap Pertumbuhan dan Hasil Sawi.

Weston, L.A. 1996. Utilization of allelopathy for weed management in agrosystem, Agronomy Journal. 


Devrnal Pertanian Tropile e-ISSN NO :2356- 4725
$\begin{array}{ll}\text { Vol.5. No.3. Desember } 2018 \text { (44) 340- } 343 & \text { https://jurnal.usu.ac.id/index.php/Tropik }\end{array}$

